\title{
Effects of nickel on the mineral composition of Fleischmann's yeast (Saccharomyces cerevisiae)
} Efeitos do niquel na composição mineral da levedura Fleischmann (Saccharomyces cerevisiae)

\author{
Samuel MARIANO-DA-SILVA ${ }^{1 *}$, Joys Dias de Assis BRAIT², Luiz Henrique Poleto ANGELONI², \\ Fabiana Maria de Siqueira MARIANO-DA-SILVA ${ }^{3}$, César Augusto Oliveira LEITE², Paula BRAGA ${ }^{2}$
}

\begin{abstract}
Sugar cane juice containing $12 \%\left(\mathrm{w}_{\mathrm{w}}^{-1}\right.$ ) of total reducing sugars and 0.0 to $5.0 \mathrm{mmol}$ of nickel $\mathrm{L}^{-1}$, with pH ranging from 3.5 to 6.5 , was

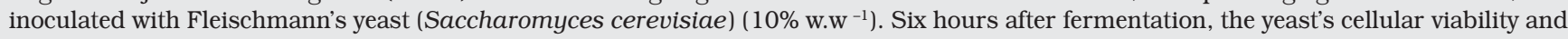
trehalose content were evaluated. The resulting must was centrifuged and the raw yeast was analyzed by atomic absorption spectroscopy to evaluate the intracellular levels of calcium, copper, iron, magnesium, manganese, nickel, phosphorus, potassium, sulfur and zinc. The intracellular levels of iron, magnesium and calcium were affected and the yeast's susceptibility to nickel was enhanced by the decrease in pH. The yeast's growth was not affected by nickel at high $\mathrm{pH}$, but the toxic effects of nickel were potentiated at low $\mathrm{pH}$.

Keywords: nickel; mineral composition; Saccharomyces cerevisiae; yeast.
\end{abstract}

\begin{abstract}
Resumo
O presente trabalho teve por finalidade estudar o acúmulo e os efeitos do níquel na composição mineral da levedura Saccharomyces cerevisiae Fleichmann fermentando mosto de caldo de cana com contaminações controladas, em níveis subtóxicos, do citado metal. O mosto esterelizado $\left(120^{\circ} \mathrm{C} / 20\right.$ minutos), com $12 \%$ de açúcares redutores totais (ART) e quatro níveis de $\mathrm{pH}(3,5 ; 4,5 ; 5,5$ e 6,5$)$, foi acrescido com o sal cloreto de níquel $\left(\mathrm{NiCl}_{2} \cdot 6 \mathrm{H}_{2} \mathrm{O}\right)$, resultando em seis níveis de contaminações $(0,0 ; 0,1 ; 0,5 ; 1,0 ; 2,0$ e 5,0 mmol Ni.L-1 $)$ e 24 tratamentos. A inoculação do mosto foi executada com fermento de panificação $\left(10 \%\right.$ p.p $\left.{ }^{-1}\right)$. Depois de 6 horas de fermentação, as leveduras foram obtidas por centrifugação, para posterior análise da viabilidade celular, dos teores de trealose, bem como dos teores celulares de níquel, fósforo, potássio, cálcio, magnésio, enxofre, cobre, ferro, manganês e zinco. O níquel parece influenciar nos teores intracelulares de ferro, magnésio e cálcio, sendo que a toxidade do níquel foi potencializa com o decréscimo do $\mathrm{pH}$.

Palavras-chave: composição mineral; levedura; níquel; Saccharomyces cerevisiae.
\end{abstract}

\section{Introduction}

Several studies have focused on the toxicity of heavy metals, particularly the toxicity associated with the phenomenon of bioaccumulation ${ }^{34}$. Several heavy metals are essential to the metabolism of microorganisms, since they are required in numerous enzymatic reactions and protein compositions. On the other hand, metal elements can be highly toxic and may disturb the microorganic metabolism.

Heavy metals comprise about 40 elements, including nickel, which has a minimum density of $6.0 \mathrm{~g} . \mathrm{cm}^{-3}{ }^{2}$. Nickel is the $28^{\text {th }}$ element in the periodic table, with an atomic weight of 58.71 g. $\mathrm{cm}^{-3}$ and specific density of $8.91^{1}$. This metal, which is usually present in soils next to mineral lodes or in deposits of industrial residues (e.g., galvanoplastic residues containing nickel), is easily absorbed by plants ${ }^{10,21,23,37}$. Nickel can even percolate into agricultural soils through server slime, through discarded cement waste, accumulated wastes from burned fossil fuel and urban garbage, among others ${ }^{1,2,36}$. The average

\footnotetext{
Recebido para publicação em 21/6/2006

Aceito para publicação em 30/7/2007 (001770)

1 Universidade Federal de Goiás - UFG, Departamento de Ciências Biológicas,

Campus de Jataí - CAJ, Rod. Br. 364, Km 192, Zona Rural,

CP 03, CEP 75800-000, Jataí - GO, Brasil,

E-mail:smarianos@uol.com.br

Universidade Federal de Goiás - UFG, Campus de Jataí - CAJ

Rod. Br. 364, Km 192, Zona Rural, CP 03, CEP 75800-000, Jataí - GO, Brasil

Universidade Estadual de Goiás - UEG,

Departamento de Tecnologia em Alimentos, Unidade Universitária de Jataí,

Av. 31 de maio, s/n, setor Epaminondas, CEP 75800-000, Jataí - GO, Brasil,

E-mail: fmdsmds@uol.com.br

*A quem a correspondência deve ser enviada
}

world values of nickel found in agricultural soils range from 20 to 40 ppm. However, MALAVOLTA ${ }^{22}$ found $127 \mathrm{ppm}$ in a structured Terra Roxa (purple soil) in the state of São Paulo.

The fermentation process normally employed in Brazil is the traditional Melle-Boinot method. Batch fermentation with total cell recycling keeps the cellular concentration high, increasing the alcohol content due to the low consumption of sugar for cell growth ${ }^{19,20}$. Due to the phenomenon of bioaccumulation, yeasts that grow by fermentation in the presence of heavy metals, even in subtoxic concentrations, may present higher cellular concentrations of these metals than those found in must ${ }^{24,26-28,32}$. This problem is believed to be aggravated when associated with yeast recycling ${ }^{25}$.

Nickel absorption by yeast depends on the sugar and metabolism, considering that dead cells do not absorb metal ${ }^{14}$. After absorption, the cations are transported through the cell membrane, probably by cation transporting proteins, to the cytosol, where they are linked to metalloproteins in the vacuole $e^{6,32,35,45}$.

Heavy metals may damage the yeast cell membrane by fluidizing it, which causes potassium channels to open and its intracellular level to decrease $e^{4,9,16}$.

Accumulation of heavy metals in the vacuole may cause calcium displacement from the vacuole, increasing free $\mathrm{Ca}^{+2}$ ions in the cytosol, which may cause the potassium exit channels to open, with loss of potassium to the surrounding medium ${ }^{4}$. $\mathrm{Mg}^{+2}$ ions are also displaced from the vacuole, passing to the cytoplasm and to the extracellular medium ${ }^{5}$. Heavy metals 
may also act directly on the SH- groups of the potassium exit channels, causing them to open and resulting in loss of potassium ${ }^{4} . \mathrm{H}^{+}$-ATPase damage is also reportedly caused by heavy metals in yeast $\mathrm{t}^{15}$.

A key component in the plasmatic membrane is $\mathrm{H}^{+}$-ATPase, which creates an electrochemical gradient through the membrane that controls the transportation of a variety of inorganic and organic solutes, such as sugar ${ }^{8,11}$.

This enzyme is clearly responsible for many physical, chemical and nutritional facts, and is usually a stress indicator, including the stress caused by heavy metals ${ }^{4}$. Heavy metals may also affect the sugar entering the yeast cell when they are linked to the anionic bindings of the plasmatic membrane. Several authors ${ }^{31,42,43}$ have reported that sugar transport into the yeast cell is inhibited by heavy metals and this inhibition may be involved in these metals' (e.g., nickel, cobalt and cadmium) interaction with the polyphosphate membrane, causing a conformational change in some active sites, which would render binding with the sugar unviable.

\section{Materials and methods}

\subsection{Material preparation}

All reusable items (glass, quartz, polyethylene, Teflon, etc.) were prepared for use by washing with detergent in ultra pure water and soaking for 4 hours in a mixture of nitric acid, hydrochloric acid and water $(1+2+9)$, followed by rinsing with ultra pure water and heat drying ${ }^{29}$.

\subsection{Yeast strain}

Blocks of pressed yeast were stored at $3{ }^{\circ} \mathrm{C} p \square$ for later use in the fermentation experiment.

\subsection{Preparation of sugar-cane juice}

For the fermentation, the juice was sterilized ( 1 ATM/20 minutes $/ 121^{\circ} \mathrm{C}$ ) and diluted with sterilized distilled water to $12 \%$ of TRS (total reducing sugars). The $\mathrm{pH}$ was adjusted to $3.5 ; 4.5 ; 5.5$ and 6.5 , according to the treatment, through the addition of $\mathrm{NaOH} 0.1 \mathrm{M}$ or $\mathrm{H}_{2} \mathrm{SO}_{4} 0.1 \mathrm{M}$. Nickel chloride salt $\left(\mathrm{NiCl}_{2} \cdot 6 \mathrm{H}_{2} \mathrm{O}\right)$ was then added to the musts, resulting in six levels of contamination $(0.0,0.1,0.5,1.0,2.0$ and $5.0 \mathrm{mmol} \mathrm{Ni} \mathrm{L}-1)$ and 24 treatments.

\subsection{Fermentation experiment}

Fermentation batches were prepared with $250 \mathrm{~mL}$ of sterilized (autoclaved at $1 \mathrm{ATM}, 120{ }^{\circ} \mathrm{C}, 20$ minutes) sugar cane must growth medium (diluted with distilled water to $16{ }^{\circ} \mathrm{Brix}$ ) and $25 \mathrm{~g}$ of yeast (uw) in $500 \mathrm{~mL}$ Erlenmeyer flasks, which were capped with aluminum foil and placed in a thermostatic oven at $30^{\circ} \mathrm{C}$ p[ . Fermentation, which was estimated by weight loss $\left(\mathrm{CO}_{2}\right)$ measured at 1 hour intervals, was concluded in 6 hours, at which point the fermented product was separated by centrifugation and analyzed.

\subsection{Viable count, budding rate and bacterial contamination}

After 18 hours of fermentation, $0.5 \mathrm{~mL}$ of each yeast sample was tested. The samples were diluted, erythrosine stained and evaluated for yeast viability, budding rate and bacterial contamination (rod type cells) by microscopic analysis, as described by AMORIM et $\mathrm{al}^{3}$.

\subsection{Yeast trehalose}

Trehalose was extracted from $60 \mathrm{mg}$ of washed cells (fresh wt) with $2 \mathrm{~mL}$ of $0.5 \mathrm{~mol} \mathrm{~L}^{-1}$ trichloroacetic acid in ice bath for 20 minutes (the suspension was shaken frequently), centrifuged $^{40,41}$, and $0.2 \mathrm{~mL}$ of each supernatant was subjected to anthrone reaction, according to Brin ${ }^{7}$.

\subsection{Nickel, potassium, calcium, magnesium, copper, manganese, and zinc quantification}

Approximately $0.5 \mathrm{~g}$ of yeast sample was mineralized by 2:5:3 sulfuric acid $\left(\mathrm{H}_{2} \mathrm{SO}_{4}\right)$, nitric acid $\left(\mathrm{HNO}_{3}\right)$ and perchloric acid $\left(\mathrm{HClO}_{4}\right)$ digestion at $220^{\circ} \mathrm{C}$ for 3 hours. The mineral content was measured by atomic absorption spectrophotometry, with atomization by acetylene flame, in a Perkin Elmer model Analyst 100 atomic absorption spectrophotometer ${ }^{44}$.

\subsection{Sulfur quantification}

Approximately 0.5 g of yeast sample was mineralized by $2: 1$ hydrogen peroxide $\left(\mathrm{H}_{2} \mathrm{O}_{2}\right)$ and perchloric acid $\left(\mathrm{HClO}_{4}\right)$ digestion at $220{ }^{\circ} \mathrm{C}$ for 3 hours. The mineralized sample was dissolved 1:100 in distilled water, after which $1 \mathrm{~mL}$ of $6 \mathrm{M}$ chloric acid $(\mathrm{HCl})$ and $0.5 \mathrm{~g}$ of barium chloride $\left(\mathrm{BaCl}_{2}\right)$ were added. After 5 minutes, the color was measured in the spectrophotometer at $420 \mathrm{~nm}^{30}$.

\subsection{Phosphorus quantification}

Approximately $0.5 \mathrm{~g}$ of yeast sample was mineralized by 2:1 hydrogen peroxide $\left(\mathrm{H}_{2} \mathrm{O}_{2}\right)$ and perchloric acid $\left(\mathrm{HClO}_{4}\right)$ digestion at $220{ }^{\circ} \mathrm{C}$ for 3 hours. The mineralized sample was dissolved 1:100 in distilled water, and $2 \mathrm{~mL}$ of $0.25 \%$ ammonium metavanadate $\left(\mathrm{NH}_{4} \mathrm{VO}_{3}\right)$ and $2 \mathrm{~mL}$ of $5 \%$ ammonium molybdate $\left(\left[\mathrm{NH}_{4}\right]_{2} \mathrm{MoO}_{4}\right)$ were added. After 15 minutes, the color was measured with a colorimeter at $660 \mathrm{~nm}^{30}$.

\subsection{Nitrogen quantification}

Approximately $0.5 \mathrm{~g}$ of yeast sample was mineralized by 2:1 hydrogen peroxide $\left(\mathrm{H}_{2} \mathrm{O}_{2}\right)$ and perchloric acid $\left(\mathrm{HClO}_{4}\right)$ digestion at $220{ }^{\circ} \mathrm{C}$ for 3 hours. The nitrogen content was then determined by the Microkjeldahl method ${ }^{30}$.

\subsection{Statistical analysis}

The variables were subjected to variance analyses ( $F$ test), following a factorial delineation in crossed model, in triplicate. The averages were compared by Tukey's multiple comparison method $^{38}$. 


\section{Results and discussion}

Tables 1 to 11 show the results obtained for nickel, phosphorus, potassium, calcium, magnesium, sulfur, copper, iron, manganese and zinc content.

The potassium content remained constant in the different treatments (Table 2), despite the slightly higher content in pH 4.5 level. Possibly, the use of higher levels of nickel would lead to massive losses of potassium caused by heavy metal, as reported by another author ${ }^{4}$.

The treatments with different concentrations of nickel interfered in the cell contents of calcium, copper and iron cell (Table 3, 5 and 8). The pH affected nickels toxicity, because the higher the $\mathrm{pH}$ the lower the intracellular calcium, copper and iron content.

The decrease in intracellular iron content indicates that nickel inhibited the ferrireductase enzyme responsible for iron absorption. This finding was previously reported in cellular treatment with cadmium ${ }^{17}$. As BLACKWELL and TOBIN ${ }^{5}$ and ASSMANN et al. ${ }^{4}$ reported for cadmium, nickel affected the intracellular magnesium and calcium contents. The accumulation of heavy metals in vacuoles probably caused displacement of the calcium and magnesium from their vacuolar storage sites, increasing the $\mathrm{Ca}^{+2}$ and $\mathrm{Mg}^{+2}$ concentrations in the cytosol. Since the plasmatic membrane is damaged by nickel, causing it to become fluidized, the transportation channels are opened, leading to a reduction of the intracellular level of free ions ${ }^{4}$.

The cellular contents of manganese, zinc, nitrogen, sulfur and phosphorus did not vary in the different treatments (Tables 9, 10, 11, 7 and 6, respectively).

The $\mathrm{pH}$ influenced nickel absorption, since higher nickel absorption occurred in $\mathrm{pH} 3.5$ than in $\mathrm{pH} 6.5$ (Table 1). At higher levels of $\mathrm{pH}$, nickel oxide and hydroxide are formed, decreasing the free ions available for interaction with the yeast $\mathrm{t}^{13}$ and thus reducing the absorption, which indicates toxicity.

Table 1. Nickel yeast content (mmol. $\mathrm{kg}^{-1}$ in dw).

\begin{tabular}{|c|c|c|c|c|c|c|}
\hline \multirow{2}{*}{$\begin{array}{c}\text { Treatment } \\
\text { pHlevel }\end{array}$} & \multicolumn{6}{|c|}{ mmol. $\mathrm{NiL}^{-1}$} \\
\hline & 0.00 & 0.10 & 0.50 & 1.00 & 2.00 & 5.00 \\
\hline 3.5 & $0.002^{\mathrm{Ea}}$ & $0.0598^{\mathrm{Da}}$ & $0.0498^{\mathrm{Da}}$ & $1.4310^{\mathrm{Ca}}$ & $3.6512^{\mathrm{Ba}}$ & $5.7877^{\mathrm{Aa}}$ \\
\hline 4.5 & $0.002^{\mathrm{Ca}}$ & $0.0344^{\mathrm{Ba}}$ & $0.0420^{\mathrm{Ba}}$ & $0.0679^{\mathrm{Bb}}$ & $0.2131^{\mathrm{Ab}}$ & $0.5643^{\mathrm{Ab}}$ \\
\hline 5.5 & $0.001^{\mathrm{Ca}}$ & $0.0523^{\mathrm{Ba}}$ & $0.0456^{\mathrm{Ba}}$ & $0.0767^{\mathrm{Bb}}$ & $0.2456^{\mathrm{Bb}}$ & $0.8765^{\mathrm{Ab}}$ \\
\hline 6.5 & $0.002^{\mathrm{Ca}}$ & $0.0604^{\mathrm{Ba}}$ & $0.0382^{\mathrm{Ba}}$ & $0.0919^{\mathrm{Bb}}$ & $0.2787^{\mathrm{Ab}}$ & $0.2398^{\mathrm{Ab}}$ \\
\hline
\end{tabular}

Standard derivation: $10.19 \%$

The averages followed by the same letters (capital or small) on the same line or same column did not differ from each other, according to the $\mathrm{F}$ and Tukey tests at $1 \%$ of confidence.

Table 2. Potassium yeast content (mol. $\mathrm{kg}^{-1}$ in dw).

\begin{tabular}{|c|c|c|c|c|c|c|}
\hline \multirow{2}{*}{$\begin{array}{c}\text { Treatment } \\
\text { pH level }\end{array}$} & \multicolumn{6}{|c|}{ mmol.Ni L ${ }^{-1}$} \\
\hline & 0.00 & 0.10 & 0.50 & 1.00 & 2.00 & 5.00 \\
\hline 3.5 & 0.3666 & 0.3922 & 0.3623 & 0.3581 & 0.3666 & 0.3922 \\
\hline 4.5 & 0.4178 & 0.4369 & 0.4497 & 0.4455 & 0.4860 & 0.3964 \\
\hline 5.5 & 0.3800 & 0.3368 & 0.3154 & 0.3261 & 0.3794 & 0.3730 \\
\hline 6.5 & 0.3218 & 0.3282 & 0.3517 & 0.3538 & 0.3581 & 0.3304 \\
\hline
\end{tabular}

Standard derivation: $17.67 \%$

According to the variance test ( $\mathrm{F}$ test), the averages did not differ from each other at $1 \%$ of confidence.

Table 3. Calcium yeast content (mmol. $\left.\mathrm{kg}^{-1} \mathrm{in} \mathrm{dw}\right)$.

\begin{tabular}{|c|c|c|c|c|c|c|}
\hline \multirow{2}{*}{$\begin{array}{c}\text { Treatment } \\
\text { pH level }\end{array}$} & \multicolumn{6}{|c|}{ mmol.Ni L ${ }^{-1}$} \\
\hline & 0.00 & 0.10 & 0.50 & 1.00 & 2.00 & 5.00 \\
\hline 3.5 & $27.86^{\mathrm{Aa}}$ & $26.61^{\mathrm{ABa}}$ & $25.87^{\mathrm{Ba}}$ & $23.70^{\mathrm{Ca}}$ & $22.25^{\mathrm{C}} \mathrm{d}^{\mathrm{a}}$ & $21.83 \mathrm{D}^{\mathrm{a}}$ \\
\hline 4.5 & $22.87^{\mathrm{Ab}}$ & $19.65^{\mathrm{Bb}}$ & $18.50^{\mathrm{Bb}}$ & $17.26^{\mathrm{BCb}}$ & $17.26^{\mathrm{BCb}}$ & $17.05 \mathrm{D}^{\mathrm{b}}$ \\
\hline 5.5 & $21.21^{\mathrm{Ab}}$ & $18.71^{\mathrm{Bb}}$ & $17.26^{\mathrm{Bb}}$ & $14.55^{\mathrm{BCc}}$ & $14.97^{\mathrm{Cc}}$ & $12.48^{\mathrm{Cc}}$ \\
\hline 6.5 & $17.05^{\mathrm{Ac}}$ & $18.71^{\mathrm{Bb}}$ & $17.05^{\mathrm{Ab}}$ & $16.22^{\mathrm{Ab}}$ & $13.72^{\mathrm{Bc}}$ & $10.19^{\mathrm{Bc}}$ \\
\hline
\end{tabular}

Standard derivation: $3.25 \%$

The averages followed by the same letters (capital or small) on the same line or same column did not differ from each other, according to the $\mathrm{F}$ and Tukey tests at $1 \%$ of confidence.

Table 4. Magnesium yeast content (mmol.kg ${ }^{-1}$ in dw).

\begin{tabular}{|c|c|c|c|c|c|c|}
\hline \multirow{2}{*}{$\begin{array}{c}\text { Treatment } \\
\text { pH level }\end{array}$} & \multicolumn{6}{|c|}{ mmol.Ni L ${ }^{-1}$} \\
\hline & 0.00 & 0.10 & 0.50 & 1.00 & 2.00 & 5.00 \\
\hline 3.5 & $56.91^{\mathrm{Aa}}$ & $52.80^{\mathrm{Ba}}$ & $53.83^{\mathrm{Ba}}$ & $51.09^{\mathrm{Ba}}$ & $50.40^{\mathrm{Ba}}$ & $46.29^{\mathrm{Ca}}$ \\
\hline 4.5 & $52.80^{\mathrm{Ab}}$ & $50.40^{\mathrm{Ab}}$ & $51.77^{\mathrm{Ab}}$ & $50.06^{\mathrm{Aa}}$ & $42.46^{\mathrm{Bb}}$ & $45.26^{\mathrm{Ba}}$ \\
\hline 5.5 & $52.46^{\mathrm{Ab}}$ & $48.34^{\mathrm{Bc}}$ & $47.32^{\mathrm{Bc}}$ & $44.91^{\mathrm{Cc}}$ & $46.29^{\mathrm{Bb}}$ & $40.11 \mathrm{D}^{\mathrm{b}}$ \\
\hline 6.5 & $46.29^{\mathrm{Ac}}$ & $47.66^{\mathrm{Ac}}$ & $48.34^{\mathrm{Ac}}$ & $47.31^{\mathrm{Ab}}$ & $45.94^{\mathrm{Ab}}$ & $39.43^{\mathrm{Bb}}$ \\
\hline
\end{tabular}

Standard derivation: $6.39 \%$

The averages followed by the same letters (capital or small) on the same line or same column did not differ from each other, according to the $\mathrm{F}$ and Tukey tests at $1 \%$ of confidence. 
Table 5. Iron yeast content (mmol.kg ${ }^{-1}$ in $\left.\mathrm{dw}\right)$.

\begin{tabular}{|c|c|c|c|c|c|c|}
\hline \multirow{2}{*}{$\begin{array}{l}\text { Treatment } \\
\text { pH level }\end{array}$} & \multicolumn{6}{|c|}{ mmol.Ni L ${ }^{-1}$} \\
\hline & 0.00 & 0.10 & 0.50 & 1.00 & 2.00 & 5.00 \\
\hline 3.5 & $14.98^{\mathrm{Aa}}$ & $13.46^{\mathrm{Aa}}$ & $15.40^{\mathrm{Aa}}$ & $14.33^{\mathrm{Aa}}$ & $13.70^{\mathrm{Aa}}$ & $10.12^{\mathrm{Aa}}$ \\
\hline 4.5 & $6.03^{\mathrm{Ab}}$ & $6.26^{\mathrm{Ab}}$ & $7.30^{\mathrm{Ab}}$ & $6.51^{\mathrm{Ab}}$ & $6.10^{\mathrm{Ab}}$ & $5.79^{\mathrm{Ab}}$ \\
\hline 5.5 & $5.68^{\mathrm{Ab}}$ & $5.88^{\mathrm{Ab}}$ & $6.66^{\mathrm{Ab}}$ & $5.68^{\mathrm{Ab}}$ & $5.03^{\mathrm{Ab}}$ & $4.40^{\mathrm{Ab}}$ \\
\hline 6.5 & $4.86^{\mathrm{Ab}}$ & $4.84^{\mathrm{Ab}}$ & $4.26^{\mathrm{Ab}}$ & $4.60^{\mathrm{Ab}}$ & $4.73^{\mathrm{Ab}}$ & $4.47^{\mathrm{Ab}}$ \\
\hline
\end{tabular}

Standard derivation: $13.21 \%$

The averages followed by the same letters (capital or small) on the same line or same column did not differ from each other, according to the $\mathrm{F}$ and Tukey tests at $1 \%$ of confidence.

Table 6. Phosphorus yeast content (mol.kg ${ }^{-1}$ in $\mathrm{dw}$ ).

\begin{tabular}{|c|c|c|c|c|c|c|}
\hline \multirow{2}{*}{$\begin{array}{c}\text { Treatment } \\
\text { pH level }\end{array}$} & \multicolumn{6}{|c|}{ mmol.Ni L ${ }^{-1}$} \\
\hline & 0.00 & 0.10 & 0.50 & 1.00 & 2.00 & 5.00 \\
\hline 3.5 & 0.3901 & 0.3794 & 0.3820 & 0.3886 & 0.3654 & 0.3390 \\
\hline 4.5 & 0.3948 & 0.3417 & 0.3662 & 0.3605 & 0.3820 & 0.3874 \\
\hline 5.5 & 0.3605 & 0.3901 & 0.3767 & 0.3632 & 0.3901 & 0.3901 \\
\hline 6.5 & 0.3767 & 0.3901 & 0.3632 & 0.3901 & 0.3767 & 0.3632 \\
\hline
\end{tabular}

Standard derivation: $5.96 \%$

According to the variance test ( $\mathrm{F}$ test), the averages did not differ from each other at $1 \%$ of confidence.

Table 7. Sulfur yeast content (mmol. $\mathrm{kg}^{-1}$ in dw).

\begin{tabular}{|c|c|c|c|c|c|c|}
\hline \multirow{2}{*}{$\begin{array}{c}\text { Treatment } \\
\text { pH level }\end{array}$} & \multicolumn{6}{|c|}{ mmol.Ni L ${ }^{-1}$} \\
\hline & 0.00 & 0.10 & 0.50 & 1.00 & 2.00 & 5.00 \\
\hline 3.5 & 60.79 & 82.14 & 92.53 & 86.82 & 92.01 & 86.14 \\
\hline 4.5 & 77.42 & 76.94 & 81.62 & 79.54 & 83.18 & 86.82 \\
\hline 5.5 & 71.74 & 69.66 & 79.02 & 79.02 & 83.70 & 86.82 \\
\hline 6.5 & 73.30 & 71.74 & 79.02 & 70.18 & 77.98 & 76.42 \\
\hline
\end{tabular}

Standard derivation: $15.45 \%$

According to the variance test ( $\mathrm{F}$ test), the averages did not differ from each other at $1 \%$ of confidence.

Table 8. Copper yeast content (mmol. $\mathrm{kg}^{-1}$ in $\left.\mathrm{dw}\right)$.

\begin{tabular}{|c|c|c|c|c|c|c|}
\hline \multirow{2}{*}{$\begin{array}{c}\text { Treatment } \\
\text { pH level }\end{array}$} & \multicolumn{6}{|c|}{ mmol.Ni L ${ }^{-1}$} \\
\hline & 0.00 & 0.10 & 0.50 & 1.00 & 2.00 & 5.00 \\
\hline 3.5 & $0.4144^{\mathrm{Aa}}$ & $0.4196^{\text {Аa }}$ & $0.4931^{\mathrm{Aa}}$ & $0.4983^{\text {Aa }}$ & $0.5036^{\mathrm{Aa}}$ & $0.3987^{\text {Aa }}$ \\
\hline 4.5 & $0.1731^{\mathrm{Ab}}$ & $0.1416^{\mathrm{Ab}}$ & $0.1259^{\mathrm{Ab}}$ & $0.1259^{\mathrm{Ab}}$ & $0.1469^{\mathrm{Ab}}$ & $0.1416^{\mathrm{Ab}}$ \\
\hline 5.5 & $0.1311^{\mathrm{Ab}}$ & $0.1626^{\mathrm{Ab}}$ & $0.1206^{\mathrm{Ab}}$ & $0.1206^{\mathrm{Ab}}$ & $0.1311^{\mathrm{Ab}}$ & $0.1154^{\mathrm{Ab}}$ \\
\hline 6.5 & $0.1574^{\mathrm{Ab}}$ & $0.1574^{\mathrm{Ab}}$ & $0.1469^{\mathrm{Ab}}$ & $0.1574^{\mathrm{Ab}}$ & $0.1679^{\mathrm{Ab}}$ & $0.1469^{\mathrm{Ab}}$ \\
\hline
\end{tabular}

Standard derivation: $15.98 \%$

The averages followed by the same letters (capital or small) on the same line or same column did not differ from each other, according to the $\mathrm{F}$ and Tukey tests at $1 \%$ of confidence.

Table 9. Manganese yeast content (mmol. $\mathrm{kg}^{-1}$ in $\left.\mathrm{dw}\right)$.

\begin{tabular}{|c|c|c|c|c|c|c|}
\hline \multirow{2}{*}{$\begin{array}{c}\text { Treatment } \\
\text { pH level }\end{array}$} & \multicolumn{6}{|c|}{ mmol.Ni L ${ }^{-1}$} \\
\hline & 0.00 & 0.10 & 0.50 & 1.00 & 2,00 & 5,00 \\
\hline 3.5 & 0.3017 & 0.3017 & 0.4389 & 0.4252 & 0.3977 & 0.3840 \\
\hline 4.5 & 0.2880 & 0.2606 & 0.2469 & 0.2331 & 0.2743 & 0.2743 \\
\hline 5.5 & 0.3154 & 0.2743 & 0.2469 & 0.2743 & 0.2880 & 0.2469 \\
\hline 6.5 & 0.3154 & 0.3292 & 0.3429 & 0.2880 & 0.3566 & 0.2194 \\
\hline
\end{tabular}

Standard derivation: $19.29 \%$

According to the variance test ( $\mathrm{F}$ test), the averages did not differ from each other at $1 \%$ of confidence.

Table 10. Zinc yeast content (mmol. $\mathrm{kg}^{-1}$ in dw).

\begin{tabular}{|c|c|c|c|c|c|c|}
\hline \multirow{2}{*}{$\begin{array}{c}\text { Treatment } \\
\text { pH level }\end{array}$} & \multicolumn{6}{|c|}{ mmol.Ni L ${ }^{-1}$} \\
\hline & 0.00 & 0.10 & 0.50 & 1.00 & 2.00 & 5.00 \\
\hline 3.5 & 3.9354 & 3.8334 & 3.7671 & 3.5938 & 3.7213 & 3.4307 \\
\hline 4.5 & 3.3950 & 3.2472 & 3.3033 & 3.3644 & 3.5479 & 3.4409 \\
\hline 5.5 & 3.3186 & 3.3287 & 3.3491 & 3.2574 & 3.3899 & 3.3236 \\
\hline 6.5 & 3.5989 & 3.6499 & 3.6601 & 3.5581 & 3.6856 & 3.3848 \\
\hline
\end{tabular}

According to the variance test ( $\mathrm{F}$ test), the averages did not differ from each other at $1 \%$ of confidence. 
Table 11. Nitrogen yeast content (g. $100 \mathrm{~g}^{-1}$ in $\left.\mathrm{dw}\right)$.

\begin{tabular}{ccccccc}
\hline $\begin{array}{c}\text { Treatment } \\
\text { pH level }\end{array}$ & \multicolumn{5}{c}{ mmol.Ni L-1 $^{-1}$} & \multicolumn{1}{c}{} \\
\cline { 2 - 7 } & 0.00 & 0.10 & 0.50 & 7.00 & 2.00 & 5.00 \\
\hline 3.5 & 6.41 & 6.63 & 7.17 & 6.22 & 7.34 & 6.55 \\
4.5 & 6.90 & 6.63 & 6.46 & 6.45 & 6.79 & 6.67 \\
5.5 & 6.20 & 6.95 & 6.52 & 6.03 & 6.30 & 6.46 \\
6.5 & 6.02 & 6.03 & 6.26 & 6.33 & 6.23 & 5.72 \\
\hline
\end{tabular}

Standard derivation: $4.32 \%$

According to the variance test ( $\mathrm{F}$ test), the averages did not differ from each other at $1 \%$ of confidence.

Tables 12, 13 and 14 show the results obtained for viability, budding rate and trehalose content. The viability rate and trehalose contents proved to be strongly correlated (Tables 12 and 14), indicating the decreasing viability as the $\mathrm{pH}$ decreased and the nickel content increased. The budding rate did not vary significantly in the different treatments (Table 13). GUTIERREZ et al. ${ }^{12}$ reported results with a similar tendency as those shown here, differing only in the maintenance of cellular viability in $\mathrm{pH} 4.0$ and contamination with $5.44 \mathrm{mmol}$ of $\mathrm{Ni} \mathrm{L}^{-1}$. In addition, those authors reported a visible decrease in trehalose content, which is congruent with the data reported in this paper.

Trehalose is associated mainly with carbohydrate storage in fungus during the nonproliferation period ${ }^{39}$. LILLIE and PRINGLE ${ }^{18}$ demonstrated that yeast survival depends on the stored trehalose level.

Figures 1 to 4 show $\mathrm{CO}_{2}$ production in the different treatments. No difference was found in the fermentative velocity in the treatments with pH 5.5 and 6.5 (Figures 3 and 4). At pH 3.5 and
4.5, the fermentative velocity was lower in the treatments with nickel than for the control (Figure 1 and 2), showing a tendency to decrease as the metal concentration increased. This behavior may be attributed to the high availability of free nickel ions ${ }^{13}$ and be correlated with the absorbed nickel content (Table 1), viability rate and trehalose content (Tables 12 and 14).

The slowest fermentation rate (Figures 3 and 4) and lowest viability rate (Figure 12) in the presence of nickel and low $\mathrm{pH}$ can be explained by the decrease in sugar absorption by yeast cells, due to the complexation of the phosphate groups of the plasmatic membrane by nickel, as proposed by VANSTEVENINCK $^{42}$ and VAN-STEVENINCK e BOOIJ ${ }^{43}$.

\section{Conclusions}

The S. cerevisiae yeast accumulated nickel at all the tested concentrations, since its accumulation potentially increases as the yeast is reused in subsequent fermentations. The $\mathrm{pH}$ affected nickel toxicity, which decreased as the $\mathrm{pH}$ increased.

Table 12. Viability rate (\%).

\begin{tabular}{|c|c|c|c|c|c|c|}
\hline \multirow{2}{*}{$\begin{array}{c}\text { Treatment } \\
\text { pH level }\end{array}$} & \multicolumn{6}{|c|}{ mmol.Ni L ${ }^{-1}$} \\
\hline & 0.00 & 0.10 & 0.50 & 1.00 & 2.00 & 5.00 \\
\hline 3.5 & $88.34^{\mathrm{Ab}}$ & $82.98^{\mathrm{Abb}}$ & $76.12^{\mathrm{Bb}}$ & $72.60^{\mathrm{Bc}}$ & $70.21^{\mathrm{Bd}}$ & $66.90^{\mathrm{Cd}}$ \\
\hline 4.5 & $99.12^{\mathrm{Aa}}$ & $95.56^{\mathrm{ABa}}$ & $89.00^{\mathrm{Bb}}$ & $84.29^{\mathrm{BCb}}$ & $80.78^{\mathrm{Cc}}$ & $76.90^{\mathrm{cc}}$ \\
\hline 5.5 & $99.77^{\text {Аa }}$ & $98.92^{\mathrm{Aa}}$ & $95.56^{\mathrm{ABa}}$ & $90.67^{\mathrm{Bb}}$ & $89.39^{\mathrm{Bb}}$ & $87.89^{\mathrm{Bb}}$ \\
\hline 6.5 & $99.56^{\mathrm{Aa}}$ & $99.20^{\mathrm{Aa}}$ & $99.67^{\mathrm{Aa}}$ & $98.90^{\mathrm{Aa}}$ & $99.54^{\mathrm{Aa}}$ & $98.07^{\mathrm{Aa}}$ \\
\hline
\end{tabular}

Standard derivation: $19.60 \%$

The averages followed by the same letters (capital or small) on the same line or same column did not differ from each other, according to the $\mathrm{F}$ and Tukey tests at $1 \%$ of confidence.

Table 13. Budding rate $(\%)$.

\begin{tabular}{|c|c|c|c|c|c|c|}
\hline \multirow{2}{*}{$\begin{array}{c}\text { Treatment } \\
\text { pH level }\end{array}$} & \multicolumn{6}{|c|}{ mmol.Ni L ${ }^{-1}$} \\
\hline & 0.00 & 0.10 & 0.50 & 1.00 & 2.00 & 5.00 \\
\hline 3.5 & 20.89 & 19.20 & 19.43 & 21.12 & 19.84 & 20.98 \\
\hline 4.5 & 21.90 & 18.16 & 20.98 & 21.34 & 21.32 & 20.94 \\
\hline 5.5 & 20.93 & 20.67 & 21.00 & 19.56 & 18.76 & 21.50 \\
\hline 6.5 & 21.90 & 19.65 & 19.67 & 18.99 & 20.01 & 19.87 \\
\hline
\end{tabular}

Standard derivation: $17.78 \%$

According to the variance test ( $\mathrm{F}$ test), the averages did not differ from each other at $1 \%$ of confidence.

Table 14. Trehalose yeast content (\%).

\begin{tabular}{|c|c|c|c|c|c|c|}
\hline \multirow{2}{*}{$\begin{array}{l}\text { Treatment } \\
\text { pH level }\end{array}$} & \multicolumn{6}{|c|}{ mmol.Ni L ${ }^{-1}$} \\
\hline & 0.00 & 0.10 & 0.50 & 1.00 & 2.00 & 5.00 \\
\hline 3.5 & $3.50^{\mathrm{Aa}}$ & $2.70^{\mathrm{Aa}}$ & $1.23^{\mathrm{Bc}}$ & $0.87^{\mathrm{Bc}}$ & $0.01^{\mathrm{Cb}}$ & $0.02^{\mathrm{cb}}$ \\
\hline 4.5 & $3.90^{\text {Аa }}$ & $3.93^{\mathrm{Aa}}$ & $2.10^{\mathrm{Bb}}$ & $1.21^{\mathrm{Cb}}$ & $0.02^{\mathrm{Db}}$ & $0.01^{\mathrm{Db}}$ \\
\hline 5.5 & $3.93^{\mathrm{Aa}}$ & $3.88^{\mathrm{Aa}}$ & $3.67^{\text {Аа }}$ & $2.99^{\mathrm{Aa}}$ & $3.00^{\mathrm{Aa}}$ & $2.97^{\text {Аа }}$ \\
\hline 6.5 & $3.81^{\text {Aa }}$ & $3.43^{\mathrm{Aa}}$ & $3.55^{\text {Аа }}$ & $3.12^{\mathrm{Aa}}$ & $3.05^{\mathrm{Aa}}$ & $3.00^{\mathrm{Aa}}$ \\
\hline
\end{tabular}

Standard derivation: $7.21 \%$

The averages followed by the same letters (capital or small) on the same line or same column did not differ from each other, according to the $\mathrm{F}$ and Tukey tests at $1 \%$ of confidence. 


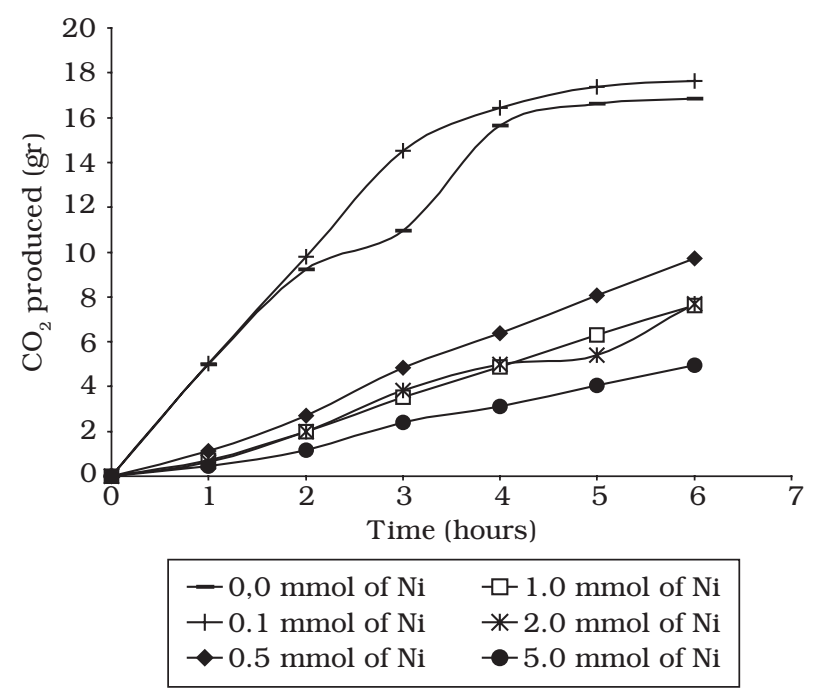

Figure 1. $\mathrm{CO}_{2}$ produced in $\mathrm{pH} 3.5$.

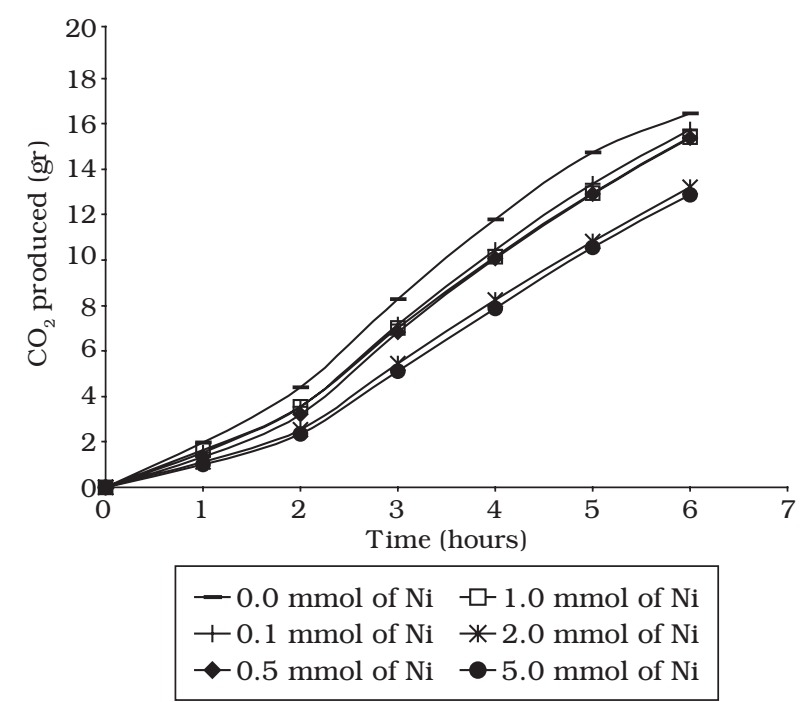

Figure 2. $\mathrm{CO}_{2}$ produced in $\mathrm{pH} 4.5$.

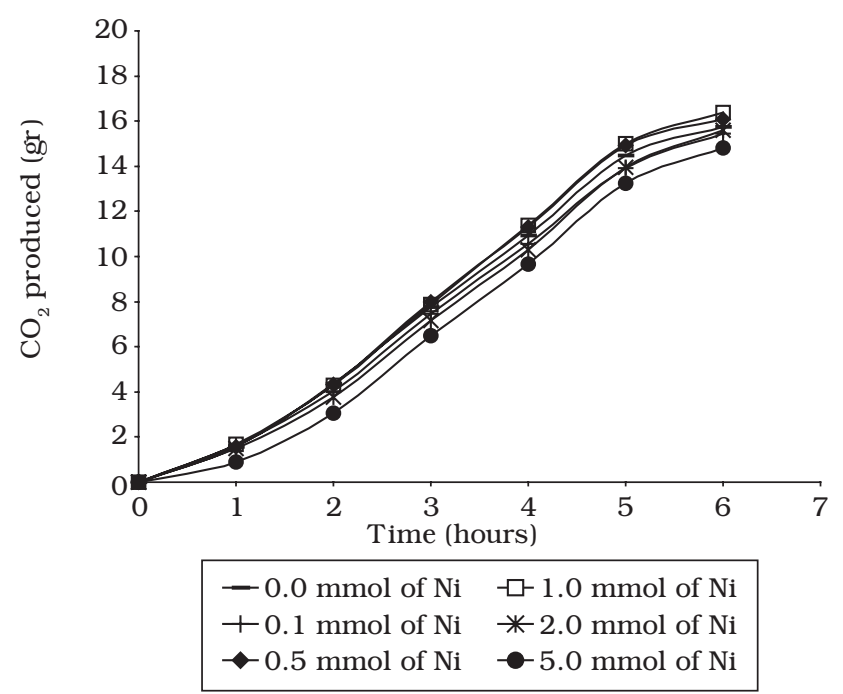

Figure 3. $\mathrm{CO}_{2}$ produced in $\mathrm{pH} 5.5$.

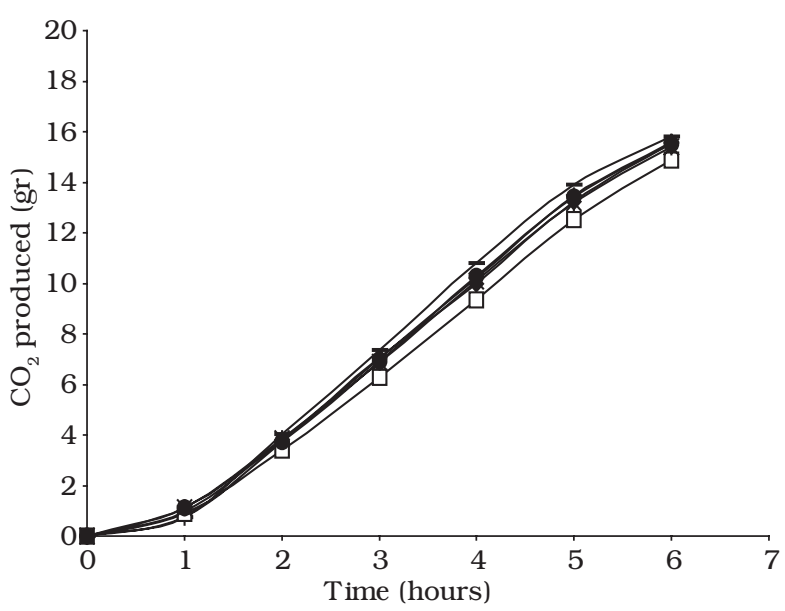

$\begin{array}{|ll|}-0.0 \mathrm{mmol} \text { of } \mathrm{Ni} & -\square-1.0 \mathrm{mmol} \text { of } \mathrm{Ni} \\ +0.1 \mathrm{mmol} \text { of } \mathrm{Ni} & -2.0 \mathrm{mmol} \text { of } \mathrm{Ni} \\ \prec-0.5 \mathrm{mmol} \text { of } \mathrm{Ni} & -5.0 \mathrm{mmol} \text { of } \mathrm{Ni}\end{array}$

Figure 4. $\mathrm{CO}_{2}$ produced in $\mathrm{pH} 6.5$.

Nickel seems to influence the intracellular content of iron, magnesium and calcium, since the results obtained here were similar to those reported in the literature for other heavy metals. The trehalose values were strongly correlated with yeast viability and growth, since this parameter reflects the physiological stress to which the yeast is subjected.

\section{References}

1. ADRIANO, D. C. Trace Elements in the Terrestrial Environment. New York: Springer-Verlang, 1986. 533 p.

2. ALLOWAY, B. I. Heavy Metals in Soils. 2. ed. New York: John Wiley, 1995. 450 p.

3. AMORIM, H. V. et al. Processos de fermentação alcoólica: seu controle e monitoramento. Piracicaba: FERMENTEC, 1989. $145 \mathrm{p}$.

4. ASSMANN, S.; SIGLER, K.; HÖFER, M. $\mathrm{Cd}^{2+}$ induced damage to yeast plasma membrane and its alleviation by $\mathrm{Zn}^{2+}$ : studies on Schizosaccharomyces pombe and reconstituted plasma membrane vesicles. Archive of Microbiology, v. 165, n. 4, p. 279-284, 1996.

5. BLACKWEEL, K. J.; TOBIN, J. M. Cadmium accumulation and its effects on intracellular ion pools in a brewing strain of Saccharomyces cerevisiae. Journal of Industrial Microbiology \& Biotechnology, v. 23, n. 3, p. 204-208, 1999.

6. BRADY, D.; DUNCAN, J. R. Bioacumulation of metal cations by Saccharomyces cerevisiae. Applied Microbiology and Biotechnology, v. 41, n. 1, p. 149-159, 1994.

7. BRIN, M. Tranketalose: clinical aspects. Methods in Enzymology, v. 9, p. 506-514, 1966.

8. BROCK, T. D. et al. Biology of Microorganisms. 7. ed. New Jersey: Prentice Hall, 1994. 909 p.

9. GADD, G. M.; MOWLL, J. L. The relationship between cadmium uptake, potassium release and viability in Saccharomyces cerevisiae. FEMS Microbiology Letters, v. 16, n. 1, p. 45-48, 1983.

10. GOUVÊA, L. C. Estudo da compostabilidade do lodo de esgoto e avaliação da distribuição química de metais pesados no 
decorrer do processo. 1995. 255 f.. Dissertação (Mestrado em Agronomia) - Universidade Federal de Viçosa, Viçosa, Brasil, 1995.

11. GRIFFIN, D. H. Fungal physiology. 2. ed. New York: John Wiley, 1994. 458p.

12. GUTIERREZ, L. E. et al. Efeito do níquel sobre Saccharomyces cerevisiae durante fermentação alcoólica. Acta Biológica Leopoldensia, v. 13, n. 2, p. 61-74, 1991.

13. HAHNE, H. C. H.; KROONTJE, W. Significance of $\mathrm{pH}$ and chloride concentration on behavior of heavy metals pollutants mercury (II), cadmium (II), zinc (II) and lead (II). Journal Environmental Quality, v. 2, n. 4, p. 444-450, 1973.

14. HELDWEIN, R.; TROMBALL, H. W.; BRODA, E. Aufnahme von Cobalt, Blei und Cadmium Durch Bäckerhefe. Zeitschrift für Allgemeine Mikrobiologie, v. 17, n. 4, p. 299-308, 1977.

15. KARAMUSHKA, V. I.; SAYER, J. A.; GADD, G. M. Inhibition of $\mathrm{H}+$ efflux form Saccharomyces cerevisiae by insoluble metal phosphates and protection by calcium and magnesium: inhibitory effects a result of metal cations? Mycological Research, v. 100, n. 6, p. 707-713, 1996.

16. KESSELS, B. G. F.; BELDE, P. M. J.; BORST-PAUWELS, G. W. F. H. Protection of Saccharomyces cerevisiae against $\mathrm{Cd}^{2+}$ toxicity by $\mathrm{Ca}^{2+}$. Journal of General Microbiology, v. 131, n. 10, p. 2.533-2.537, 1985 .

17. LESUISSE, E.; LABBE, P. Effects of cadmium and of YAP1 and CAD1/YAP2 genes on iron metabolism in the yeast Saccharomyces cerevisiae. Microbiology, v. 141, n. 11, p. 2.935-2.943, 1995.

18. LILLIE, S. H.; PRINGLE, J. R. Reserve carbohydrate metabolism in Saccharomyces cerevisiae: response to nutrient limitation. Journal of Bacteriology, v. 143, n. 3, p. 1384-1394, 1980.

19. LIMA, G. J. M. M. Uso da levedura seca (Saccharomyces cerevisiae) de destilarias de álcool de cana-de-açúcar na alimentação de matrizes suínas em gestação e lactação. 1983. 139 f.. Dissertação (Mestrado em Agronomia) - Escola Superior de Agricultura "Luiz de Queiroz", Universidade de São Paulo, Piracicaba, 1983.

20. LOPES, J. J. C. Bagaço de nutrientes minerais no processo Melle-Boinot de fermentação alcoólica. 1989. 74 f.. Dissertação (Mestrado em Agronomia) - Escola Superior de Agricultura "Luiz de Queiroz”, Universidade de São Paulo, Piracicaba, 1989.

21. MALAVOLTA, E. Elementos de nutrição mineral de plantas. São Paulo: Editora Agronômica Ceres, 1980. 251 p.

22. Fertilizantes e seu impacto ambiental - micronutrientes e metais pesados: mitos, mistificação e fatos. São Paulo: Produquímica, 1994. 154 p.

23. Manual de química agrícola. São Paulo: Agronômica Ceres, 1976. 528 p.

24. MARIANO-da-SILVA, S. Acúmulo de cádmio por Saccharomyces cerevisiae fermentando mosto de caldo de cana. 1998. 45f.. Dissertação (Mestrado em Agronomia) - Escola Superior de Agricultura "Luiz de Queiroz", Universidade de São Paulo, Piracicaba, 1998.

25. Efeitos do cádmio sobre a fermentação alcoólica e o uso da vinhaça para atenuar a sua ação tóxica. 2001. $134 \mathrm{f}$.. Tese (Doutorado em Agronomia) - Escola Superior de Agricultura "Luiz de Queiroz”, Universidade de São Paulo, Piracicaba, 2001.

26. MARIANO-da-SILVA, S.; BASSO, L. C. Efeitos do cádmio sobre o crescimento das leveduras Saccharomyces cerevisiae PE-2 e Saccharomyces cerevisiae IZ-1904, e a capacidade da vinhaça em atenuar a toxidade. Ciência e Tecnologia de Alimentos, v. 24, n. 1, p. 16-22, 2004.

27. MARIANO-da-SILVA, S.; PRADO-FILHO, L. G. Acúmulo de Cádmio por Saccharomyces cerevisiae em caldo de cana-deaçúcar contaminado com acetato de cádmio. Scientia Agricola, v. 56, n. 2, p. 427-431, 1999.

$28 . \quad$ ______. Acúmulo de cádmio por Saccaromyces cerevisiae fermentando mosto de caldo-de-cana. Ciência e Tecnologia de Alimentos, v. 18, n. 4,p. 410-413, 1998.

29. McDANIEL, W. Sample preparation procedure for spectrochemical determination of total recoverable elements in biological tissues. In: SMOLEY, C. K. Methods for the determination of metals in environmental samples. Boca Ranton: CRC Press, 1992. cap. 3, p.613-625.

30. MIYAZAWA, M. et al. Análises químicas de tecido vegetal. In. SILVA, F. C. Manual de analises químicas. EMBRAPA: Brasília, 1999. cap. 4, p.173-224.

31. NAKAMURA, H. Adaptation of yeast to cadmium VII. Significance of polyphosphate in cadmium resistance. Botanical Magazine, v. 78, n. 1, p. 85-90, 1965.

32. NORRIS, P. R.; KELLY, D. P. Accumulation of cadmium and cobalt by Saccharomyces cerevisiae. Journal of General Microbiology, v. 99, n. 2, p. 317-324, 1977.

33. PRADO-FILHO, L. G.; DOMINGOS, R. N.; MARIANO-da-SILVA, S. Acúmulo de cádmio por Saccharomyces cerevisiae fermentando em mosto de melaço. Scientia Agrícola, v. 55, n. 1,p. 128-132, 1998.

34. ROBARDS, K.; WOURSFOLD, P. Cadmium. Analyst, v. 116 , n. 6, p. 549-568, 1991.

35. RÖSICK, E.; MANGIR, M.; LOCHMANN, E. R. Unterschiedlich Aufnahme von Cadmium in Saccharomyces - BZW. Rhodotorula - zellen. Chemosphere, v. 15, n. 8, p. 981-983, 1986.

36. SAlGADO, P. E. T. Toxicologia dos Metais. In: OGA, S. Fundamentos de toxicologia. São Paulo: Atheneu Editora, 1996. cap.3.2, p.153-172.

37. SILVA, F. C. Uso agronômico do lodo de esgoto: efeitos em fertilidade do solo e qualidade da cana-de-açúcar. 1995. 165 f.. Tese (Doutorado em Agronomia) - Escola Superior de Agricultura "Luiz de Queiroz", Universidade de São Paulo, Piracicaba, 1995.

38. SNEDECOR, G. W.; COCHRAN, W. G. Statistical methods. 6. ed. Ames: The Iowa State University Press, 1967. 593 p.

39. THEVELEIN, J. M. Regulation of trehalose mobilization in fungi. Microbiological Reviews, v. 48, n. 2, p. 42-59, 1984

40. TREVELYAN, W. E.; HARRISON, J. S. Studies on yeast metabolism 5. The trehalose content of baker's yeast during anaerobic fermentation. Biochemical Journal, v. 62, n. 2, p. 177-183, $1956 a$.

41. _____. Studies on yeast metabolism 7. Yeast carbohydrate fraction. Separation from nucleic acid analysis and behavior during anaerobic fermentation. Biochemical Journal, v. 63, n. 1, p. 23-33, 1956b.

42. VAN-STEVENNINK, J.; The inlfuence of nickelous ions on carbohydrate transport in yeast cells. Biochimica et Biophysica Acta, v. 126, n. 1, p. 154-162, 1966.

43. VAN-STEVENNINK, J.; BOOIJ, H. L. The role of polyphosphates in the transport mechanism of glucose in yeast cells. Journal of General Physiology, v. 48, n. 1, p. 43-60, 1964 
44. VARMA, A. Group IIB elements ( $\mathrm{Zn}, \mathrm{Cd}, \mathrm{Hg}$ ). In: VARMA, A. Handbook of atomic absorption analysis. Boca Ranton: CRC Press, 1986. 3. ed, v. 2, p. 73-184.
45. VOLESKY, B. Biosorption by fungal biomass. In: VOLESK, B. Biosorption of Heavy Metals. Boca Ranton: CRC Press, 1990. p. $139-172$. 